\title{
PERIKANAN BUNBUN (BRUSH PARK FISHERIES) DI SITU BAGENDIT KABUPATEN GARUT PROPINSI JAWA BARAT
}

\author{
Amula Nurfiarini dan Kunto Purnomo \\ Peneliti pada Loka Riset Pemacuan Stok Ikan, Jatiluhur-Purwakarta \\ Teregristrasi I tanggal: 17 Desember 2008; Diterima setelah perbaikan tanggal: 13 Pebruari 2009; \\ Disetujui terbit tanggal: 19 Maret 2009
}

\begin{abstract}
ABSTRAK
Situ Bagendit, Kabupaten Garut Propinsi Jawa Barat mempunyai luas 20-57 ha dan berfungsi utama sebagai obyek wisata ziarah, meskipun aktivitas lainnya juga berkembang cukup pesat, yakni perikanan tangkap. Bunbun merupakan salah satu jenis alat tangkap yang menyerupai rumpon, berbahan ranting bambu dengan luas $15-30 \mathrm{~m}^{2}$. Bunbun dioperasikan dengan cara menenggelamkan rumpon yang telah diberi tiang penahan ke perairan pada kedalaman tertentu, dan membiarkannya selama suatu periode tertentu. Pemanenan ikan dilakukan dengan menggunakan bantuan perangkap bambu (wide). Produksi tangkapan bunbun berkisar antara 40-60 kg/unit/musim dengan jenis dan ukuran ikan sangat beragam. Hasil analisis usaha menunjukkan bahwa untuk setiap 5 unit bunbun yang dioperasikan dengan periode penenggelaman 3 bulan akan menghasilkan nilai produksi sebesar Rp 2.192.250, dan keuntungan bersih Rp.558.775 per musim dengan nilai B/C ratio sebesar 2,03. Artinya, bahwa usaha penangkapan dengan bunbun cukup layak diusahakan. Namun demikian perlu diwaspadai bahwa perkembangan bunbun yang pesat tanpa diiringi aturan mengenai jumlah optimal yang diperkenankan, lokasi peletakkan, dan sistem operasional bunbun termasuk pemeliharaannya, keberadaan bunbun dapat mengurangi nilai estetika situ, bahkan dapat mempercepat terjadinya pendangkalan.
\end{abstract}

KATAKUNCI: $\quad$ perikanan, bunbun, keuntungan, ancaman, Situ Bagendit

\section{PENDAHULUAN}

Situ Bagendit, secara administrasi terletak di Kecamatan Banyuresmi, Kabupaten Garut, Jawa Barat. Situ dengan fluktuasi luas 20-57 ha dan berada pada ketinggian $400 \mathrm{~m}$ dpl mendapatkan pasokan air dari hujan dan beberapa sungai kecil di sekitarnya. Jarak lokasi situ ini dengan ibu kota kecamatan dan Kota Garut adalah 3 dan $15 \mathrm{~km}$ dan dapat dicapai dengan kendaraan umum. Situ Bagendit memiliki fungsi utama sebagai obyek wisata ziarah, meskipun aktivitas lain juga cukup berkembang, di antaranya perikanan tangkap. Letaknya sangat dekat dengan pemukiman penduduk yang padat dan kemudahan akses menuju perairan, telah menyebabkan aktivitas penangkapan ikan menjadi intensif. Berbagai macam alat tangkap yang digunakan antara lain sirip, beko, syair, sirip udang, pancing, jaring, dan bunbun. Dari beberapa alat tangkap tersebut, jenis sirip udang dan bunbun merupakan alat tangkap dominan.

Bunbun merupakan alat tangkap yang menyerupai rumpon (brush park system) yang berfungsi sebagai tempat berkumpul ikan yang pada saat tertentu akan dipanen secara periodik. Pada beberapa perairan di Indonesia baik tawar maupun laut, selain dimanfaatkan sebagai alat tangkap, rumpon juga cukup efektif difungsikan sebagai suaka perikanan. Meskipun nilai investasi alat tangkap ini relatif mahal, yakni
Rp.500.000-1.000.000, hampir setiap nelayan di Situ Bagendit memiliki alat tangkap tersebut, karena penangkapan ikan dengan bunbun cukup menghemat tenaga kerja, dan menjanjikan hasil tangkapan cukup baik. Pada saat ini jumlah bunbun yang beroperasi di perairan mencapai 500 unit, sebuah angka yang cukup fantastik, mengingat luas perairan yang relatif tidak luas, apalagi jika musim kemarau hampir separuh perairan mengering hingga kedalaman airnya hanya mencapai $0,5 \mathrm{~m}$. Dalam kondisi tersebut, apakah perikanan bunbun layak diusahakan, berapa besar tingkat kelayakannya, dan bagaimanakah pengaruhnya bagi keberlanjutan lingkungan. Tulisan ini mengulas tentang aktivitas perikanan bunbun termasuk pengaruh terhadap lingkungan yang kemungkinan timbul akibat pengembangannya.

\section{DESKRIPSI ALAT TANGKAP BUNBUN}

Bunbun di Situ Bagendit pada umumnya terbuat dari susunan batang dan ranting bambu yang berfungsi sebagai rumpon (rumah ikan). Pada setiap sisinya, tumpukan ranting tersebut ditahan oleh tiang penahan berbahan bambu dengan tujuan untuk mencegah kemungkinan berpindahnya tumpukan. Satu unit bunbun memiliki luas yang beragam, ada yang berukuran 2,0×3,0×5,0 m (Gambar 1). Berbeda dengan di Limboto, alat tangkap rumpon menggunakan bahan dasar gulma enceng gondok atau lebih dikenal 


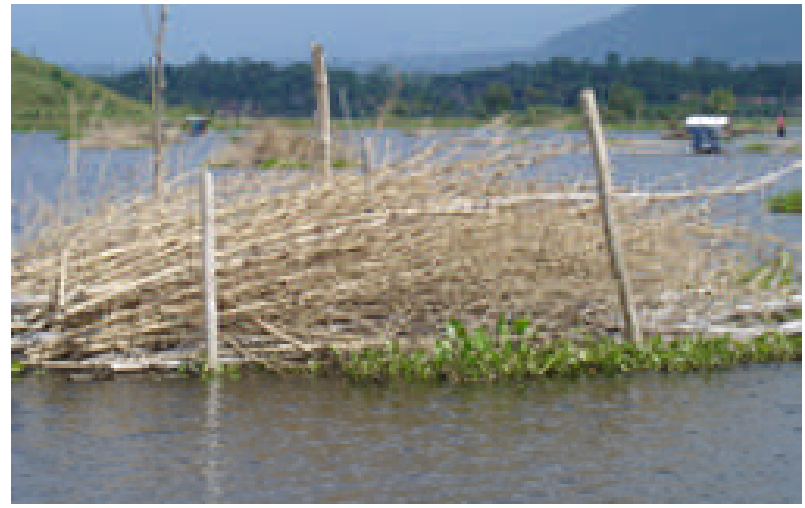

Gambar 1. Alat tangkap bunbun.

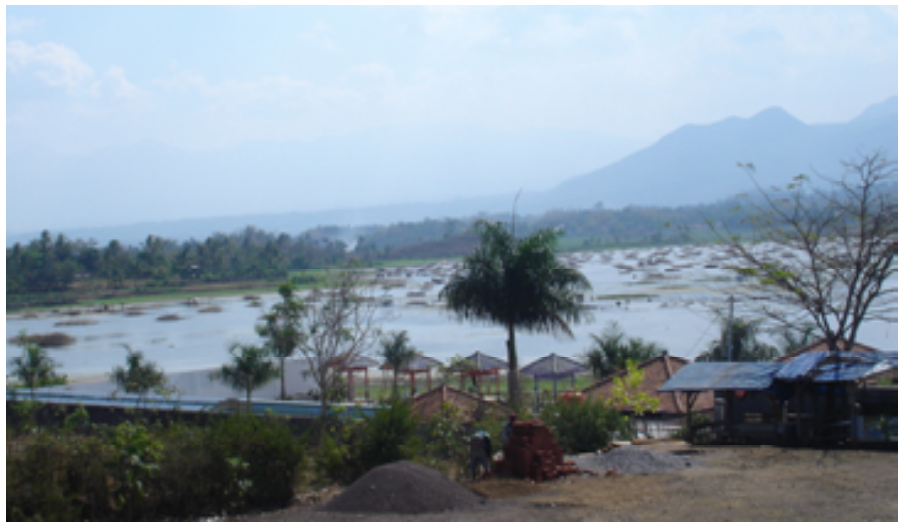

Gambar 2. Alat tangkap bunbun pada musim kemarau.

dengan sebutan bibilo, memiliki luas $200 \mathrm{~m}^{2}$ setiap unitnya (Suryandari, 2007). Bunbun memiliki umur ekonomis relatif lama, yakni dapat mencapai 10 tahun. Di Situ Bagendit, bunbun diperkirakan menutupi perairan seluas 5 ha atau sekitar $4,8-25,0 \%$ dari luas total perairan.

Welcome (2001) mengatakan bahwa ada beberapa faktor yang mempengaruhi seseorang dalam memilih satu jenis alat tangkap, antara lain musim, kondisi keuangan nelayan, lokasi penangkapan, dan ikan sasaran. Alat tangkap bunbun dapat dioperasikan sepanjang tahun, namun waktu efektifnya hanya pada saat air penuh hingga menjelang surut. Jika sudah memasuki musim kemarau, dan sebagian perairan mulai mengering, bunbun menjadi tidak efektif lagi karena sebagian besar bunbun berada di daratan (Gambar 2). Bunbun juga merupakan alat tangkap yang memerlukan investasi cukup besar. Untuk setiap unit bunbun yang berukuran $3,0 \times 5,0 \times 2,5 \mathrm{~m}$ memerlukan biaya investasi Rp.500.000-1.000.000. Hal tersebut disebabkan oleh bahan baku pembuatan bunbun berasal dari luar daerah. Sehingga nelayan yang menggunakan alat tersebut, pada umumnya nelayan pemilik modal besar. Sedangkan ikan sasaran dari alat tersebut bersifat multi spesies, artinya, hampir semua jenis ikan di perairan dapat tertangkap dengan alat tersebut.

\section{AKTIVITAS PENANGKAPAN DENGAN BUNBUN}

\section{Operasionalisasi Alat Tangkap}

Bunbun dapat dipanen setiap saat. Namun untuk mengoptimalkan hasil tangkapan serta mengefektifkan penggunaan tenaga kerja, pada umumnya bunbun dipanen secara periodik ( 1 bulan sekali), dan panen raya setahun sekali yang dilakukan pada saat air surut (musim kemarau).

Penangkapan atau pemanenan diawali oleh pengurungan ikan dengan menggunakan alat bantu berupa pagar terbuat dari bambu yang dirangkai rapat seperti tirai atau lebih dikenal dengan sebutan wide. Kemudian diteruskan oleh pemindah bunbun keluar dari dalam kurungan, lalu ikan diambil dengan alat seser sedikit demi sedikit sampai ikan dalam kurungan habis. Peran wide dapat digantikan oleh kurungan berbahan waring, namun di Situ Bagendit, penggunaan waring sebagai pengganti wide hampir tidak dijumpai. 


\section{Hasil Tangkapan}

Hasil tangkapan bunbun sangat beragam baik jenis maupun ukurannya. Pengamatan pada saat kegiatan panen raya menunjukkan bahwa bunbun berukuran $15 \mathrm{~m}^{2}$ dan umur penenggelaman kurang lebih 3 bulan memberikan hasil kurang lebih $60 \mathrm{~kg}$. Jumlah spesies ikan yang tertangkap mencapai 12 jenis (Tabel 1). Ikan-ikan yang tertangkap pada umumnya merupakan ikan konsumsi. Berdasarkan pada bobot, hasil tangkapan didominansi oleh jenis ikan nila, mujair, gabus, dan sepat.

\section{Analisis Kelayakan Usaha}

\section{Biaya Investasi}

Investasi yang diperlukan dalam usaha perikanan bunbun berupa peralatan antara lain, bambu (termasuk batang dan ranting), batang bambu penahan, alat pengurung (wide), dan seser. Hasil wawancara menunjukkan bahwa seorang nelayan pada umumnya memiliki bunbun \pm 5 unit, sehingga rata-rata total nilai investasi adalah Rp 4.390.000 (Tabel 2).

\section{Biaya Operasional}

Biaya yang dikeluarkan nelayan dalam pengoperasian alat tangkap bunbun berupa biaya tetap (fixed cost) yakni biaya penyusutan perahu, alat tangkap, peralatan pendukung, serta biaya pemeliharaan alat dan biaya tidak tetap (variabel cost) berupa biaya konsumsi tenaga pemanen. Pemanenan bunbun dilakukan oleh 2-4 orang tenaga kerja. Biaya tetap dapat mencapai Rp.584.700,-/tahun, sedangkan biaya variabel berkisar Rp. 20.000 - 50.000/unit/musim (Tabel 3).

\section{Pendapatan Usaha}

Kegiatan pemanenan dilakukan setelah umur bunbun kurang lebih 3 bulan, namun sebagian besar nelayan bunbun skala kecil memanen ikannya secara berangsur-angsur setiap 2 minggu sekali. Hasilnya tentu berbeda dengan bunbun yang dipanen berkala.

Dalam satu kali pemanenan, dengan rata-rata masa penenggelam alat sekitar 3 bulan, 1 unit bunbun berukuran $15 \mathrm{~m}^{2}$ dapat menghasilkan ikan $40-60 \mathrm{~kg}$. Di lokasi penelitian, seorang nelayan rata-rata memiliki bunbun antara 3-5 unit per nelayan, bahkan untuk nelayan yang bermodal besar, jumlah bunbun yang dimiliki dapat mencapai 20 unit. Dengan hasil tersebut, diperoleh nilai produksi Rp 2.192.250, dan setelah melalui sistem bagi hasil dengan para pekerja, seorang nelayan dapat mengantongi keuntungan bersih $\mathrm{Rp} 584.700$ per musim dengan nilai $\mathrm{B} / \mathrm{C}$ ratio 2,03 .

Tabel 1. Komposisi hasil tangkapan ikan, harga, dan nilai produksi pada penangkapan sistem bunbun

\begin{tabular}{|c|c|c|c|c|}
\hline \multirow[b]{2}{*}{ Jenis } & \multicolumn{2}{|c|}{ Bobot produksi } & \multirow{2}{*}{$\begin{array}{l}\text { Harga } \\
\text { (Rp./kg) }\end{array}$} & \multirow{2}{*}{$\begin{array}{l}\text { Nilai produks } \\
\text { (Rp.) }\end{array}$} \\
\hline & $\mathbf{k g}$ & $\begin{array}{c}\text { Persentase } \\
(\%)\end{array}$ & & \\
\hline Nila (Oreochromis niloticus) & 23,00 & 38,67 & 10.000 & 232.000 \\
\hline Mujair (Oreochromis mossambicus) & 9,10 & 15,50 & 4.500 & 41.850 \\
\hline Betok (Anabas testudineus) & 2,60 & 4,33 & 4.500 & 11.690 \\
\hline Sepat (Tricogaster pectoralis/T.tricopterus) & 7,50 & 13,00 & 4.500 & 35.100 \\
\hline Gabus/delek (Channa striata) & 6,20 & 10,33 & 10.000 & 61.980 \\
\hline Oskar (Amphilophus citrinellus) & 4,50 & 7,33 & 4.500 & 19.790 \\
\hline Nilem (Cyclocheilhtys Apogon) & 3,20 & 5,33 & 4.500 & 14.390 \\
\hline Julung-julung (Dermogenis pussilus) & 1,20 & 2,00 & 4.500 & 5.400 \\
\hline Reges (Rasbora argyotaenia) & 2,20 & 3,50 & 4.500 & 9.450 \\
\hline Udang (Caridina sp.) & 0,50 & 0,67 & 17.000 & 6.800 \\
\hline Total & 60,00 & 100,00 & - & 438.450 \\
\hline
\end{tabular}

Tabel 2. Nilai investasi alat tangkap bunbun dan umur ekonomis alat

\begin{tabular}{clccc}
\hline No. & \multicolumn{1}{c}{ Peralatan } & $\begin{array}{c}\text { Jumlah } \\
\text { (unit) }\end{array}$ & $\begin{array}{c}\text { Umur ekonomis } \\
\text { (tahun) }\end{array}$ & $\begin{array}{c}\text { Nilai Investasi } \\
\text { (Rp) }\end{array}$ \\
\hline 1. & Bunbun ukuran $15 \mathrm{~m}^{2}$ & 5 & 10 & 3.500 .000 \\
2. & Bambu penahan & 30 & 5 & 240.000 \\
3. & Wide (alat pengurung) & 1 & 10 & 100.000 \\
4. & Seser & 2 & 5 & 50.000 \\
5. & Rakit & 1 & 3 & 500.000 \\
\hline & Total investasi & & & $\mathbf{4 . 3 9 0 . 0 0 0}$ \\
\hline
\end{tabular}


Tabel 3. Biaya penyusutan alat tangkap bunbun (Rp./musim)

\begin{tabular}{lcc}
\hline \multicolumn{1}{c}{ Uraian } & Penyusutan/tahun (Rp.) & $\begin{array}{c}\text { Penyusutan/musim } \\
\text { penangkapan (Rp.) }\end{array}$ \\
\hline Penyusutan Alat & 166.700 & 83.350 \\
- rakit & 350.000 & 175.000 \\
- Alat Tangkap/bunbun & 48.000 & 24.000 \\
- Bambu penahan & 20.000 & 10.000 \\
- Peralatan pendukung & & $\mathbf{2 9 2 . 3 5 0}$ \\
\hline Total Biaya Tetap & $\mathbf{5 8 4 . 7 0 0}$ & \\
\hline
\end{tabular}

") periode 3 bulan

Alat sejenis bunbun yaitu bibilo di Danau LimbotoGorontalo (rumpon berbahan gulma enceng gondok) dan rebo di Danau Teluk Jambi (rumpon berbahan ranting kayu) masing-masing berukuran 100 dan $15 \mathrm{~m}^{2}$, masing-masing menghasilkan ikan 400 dan 30 $\mathrm{kg}$ dalam satu kali panen (Suryandari, 2007). Kondisi tersebut diduga juga dipengaruhi oleh potensi produksi perairan dan intensitas penangkapan.

\section{SELEKTIVITAS ALAT TANGKAP}

Selektivitas alat tangkap adalah fungsi alat tangkap untuk menangkap organisme (ikan) yang terbatas pada spesies dan kisaran ukuran tertentu dalam suatu populasi yang ditemui di daerah penangkapan tertentu (Arimoto, 1999). Hasil tangkapan bunbun menunjukkan bahwa jenis dan ukuran ikan yang sangat beragam, mulai dari ukuran kecil (anakan) hingga besar (induk ikan). Dengan demikian dapat dikatakan bahwa bunbun tidak mempunyai sasaran yang spesifik sehingga alat tersebut menjadi tidak selektif terhadap objek tangkapan.

\section{KEUNGGULAN DAN DAMPAK}

Pemakaian alat tangkap bunbun bayak diminati oleh masyarakat, pada umumnya para nelayan sambilan, karena pengunaan bunbun menghemat dalam penggunaan tenaga kerja, tidak memerlukan perawatan khusus terhadap alat yang dioperasikan, tidak membutuhkan ketrampilan tertentu dalam pengoperasiannya, dan hasil dapat dipanen kapan saja dibutuhkan. Namun demikian, untuk perekonomian nelayan, usaha ini memerlukan investasi yang relatif besar. Meskipun hasil panenan cukup menjanjikan, namun tanpa pengawasan bukan tidak mungkin usaha ini kurang memberikan kepastian hasil. Hal tersebut mengingat tingginya intensitas penangkapan, dan juga membuka peluang bagi berkembangnya aktivitas pencurian ikan. Kondisi lebih parah yang ditimbulkan dari perikanan bunbun ini adalah masa terdekomposisinya bambu menjadi seresah yang memerlukan waktu lebih dari 20 tahun, sehingga memicu laju pendangkalan situ, dan pada akhirnya akan mempengaruhi kualitas lingkungan perairan serta nilai estetika danau mengingat potensi pariwisata di Situ Bagendit cukup menjanjikan.

\section{KESIMPULAN}

Bunbun merupakan salah satu jenis alat tangkap menyerupai rumpon (brush park system) berbahan ranting bambu. Bunbun banyak dikembangkan di Situ Bagendit karena hemat tenaga kerja dan relatif menguntungkan. Namun perlu diwaspadai, karena perkembangan bunbun yang pesat tanpa diiringi aturan mengenai jumlah optimal yang diperkenankan, lokasi peletakan dan sistem operasional bunbun termasuk pemeliharaan, keberadaan bunbun dapat merusak keindahan situ, bahkan dapat mempercepat terjadinya pendangkalan.

\section{PERSANTUNAN}

Kegiatan dari hasil riset perikanan berbasis budi daya (culture based fisheries) di Danau/Situ/Waduk di Jawa Barat dan Jawa tengah, T. A. 2008, di Loka Riset Pemacuan Stok Ikan, Jatiluhur-Purwakarta.

\section{DAFTAR PUSTAKA}

Arimoto T. 1999. Fish Behaviour for Improving Fish Capture Technology. Tokyo University of Fisheries. Japan. 55 pp.

Welcomme, R. I. 2001. Inland Fisheries: Ecology and Management. Blackwell Sciensce. U. K.

Suryandari , A. \& Nanang, W. 2007. Perikanan bibilo di Danau Limboto. Penelitian Rehabilitasi Habitat dan Konservasi Sumber Daya Perikanan Danau Limboto. Unpublish.

http://qomm.wordpress.com/rumah-bambu. 2007. Karamba bambu, berapa lama bisa bertahan. 